\title{
Screening of Chemical Compounds for Selectively Inhibiting Haustorial Formation of Powdery Mildew Pathogen in Barley Coleoptile Epidermis
}

\author{
Mitsue DoHGo*, Hideyoshi ToyodA*, Yoshinori MATSUdA*** \\ Kazuhiko MATSUDA**, Yukie KOKURYO* \\ and Seiji OUCHI*
}

Key words : barley powdery mildew, antifungal activity, tryptamine, indole-3-propionic acid.

In our attempts to establish an efficient system for fungal transformation, we have elaborated a microinjection technique for specifically introducing the genes into targeted infection structures ${ }^{4,6,9,11)}$ and demonstrated that the reporter gene ( $\beta$-glucuronidase gene) flanked to the cauliflower mosaic virus $35 \mathrm{~S}$ promoter was functionally transcribed in fungal cells ${ }^{5,8}$. . This microinjection technique was also applicable to the transformation of obligate fungal pathogens such as powdery mildew fungi ${ }^{5,6)}$. The reporter gene was microinjected most effectively into appressoria of the powdery mildew pathogen inoculated into barley coleoptile epidermis and the expression of the gene was detected in primary haustoria produced by the gene-injected appressoria ${ }^{5}$. These results suggest that the successfully transformed pathogens could be rapidly and effectively detected by checking the survival of the haustoria if some selective markers are integrated in our transformation system. From this point of view, we have focused on the screening of chemical compounds capable of selectively inhibiting the growth of powdery mildew fungi without causing detrimental effect on barley plants. In a series of works for screening chemical agents for soil-borne pathogens of tomato, we found that some indole derivatives (indole-3-propionic acid and indole-3-acrylic acid) were capable of inhibiting the growth of Pseudomonas solanacearum $^{3,10)}$, and these compounds were also inhibitory to some fungal pathogens including Erysiphe cichoracearum, the causal pathogen of powdery mildew of tomato. Recently, Miyagawa et $a l^{7}{ }^{7}$ reported that tryptamine was produced in UV-injured or powderymildewed barley leaves, and that the compound inhibited the conidial germination of E. graminis f. sp. hor$d e i$. These results suggest a possible application of some indole derivatives to selective chemical agents for the powdery mildew pathogen. In the present study, therefore, we examined some related compounds of indole-3- propionic acid and tryptamine for their antifungal activities and selected the compounds which specifically inhibit the haustorial formation of E. graminis $\mathrm{f}$. sp. hordei.

Coleoptile epidermis was excised from 10-day-old seedlings of barley (Hordeum vulgare, L., cv. Kobinkatagi, susceptible to race I) and inner epidermis was used in the following experiment. First, the toxicity of test compounds to host cells was examined by floating the epidermis onto a test solution $(0.5 \%$ methanol solution containing 10,50 , and $100 \mu \mathrm{g} / \mathrm{ml}$ of test compounds) at $20^{\circ} \mathrm{C}$ for $48 \mathrm{hr}$ according to the method of Koga et $a l^{2)}$ The survival of coleoptile epidermal cells was determined by microscopically observing their cytoplasmic streaming and the cells maintaining cytoplasmic streaming were regarded as survived cells. The result is given in Table 1. Indole-3-acetamide, tryptamine, tryptophol, and tryptophan did not exhibit significant effect on cell activity (more than $90 \%$ in the survival rate) even when the epidermis was treated at the highest concentration (100 $\mu \mathrm{g} / \mathrm{ml})$. Other six compounds (indole, indole-3carboxylic acid, indole-3-glyoxylic acid, indole-3-lactic acid, indole-3-propionic acid, and indole-3-butyric acid) also gave high survival rates of host epidermal cells when these compounds were added to the test solution at lower concentrations ( 10 or $50 \mu \mathrm{g} / \mathrm{ml})$. In the present study, therefore, we selected these non-toxic or lowtoxic compounds for examining their specific antifungal activity at the concentrations which did not cause the cell death of host coleoptile tissues. Namely, excised inner epidermis of coleoptile was inoculated with fresh conidiospores of E. graminis f. sp. hordei (race I) by the method described previously ${ }^{9)}$ and floated onto the test solution mentioned above. After $48 \mathrm{hr}$ of incubation, the epidermis was vitally observed under an Olympus differential phase contrast microscope to determine the fungal development or host cell survival. Figure 1 shows

* Laboratory of Plant Pathology and ** Laboratory of Pesticide Chemistry, Faculty of Agriculture, Kinki University, Nakamachi 3327-204, Nara 631, Japan＼cjkstart近畿大学農学部

*** The Institute for Comprehensive Agricultural Sciences, Kinki University, Nakamachi 3327-204, Nara 631, Japan 近 畿大学農学総合研究所 
Table 1. Phytotoxic effect of indole and indole derivatives on coleoptile epidermal cells of barley

\begin{tabular}{lccc}
\hline \hline & & Survival rates $(\%)^{\mathrm{a})}$ & \\
\cline { 2 - 4 } Test compounds ${ }^{\mathrm{b})}$ & 10 & 50 & $580^{\mathrm{c}}$ \\
\hline indole & $96.3(2.5)$ & $95.8(0.6)$ & 0 \\
indole-2-carboxylic acid & $5.3(3.3)$ & 0 & $30.0(0.3)$ \\
indole-2-carboxylic acid ethyl ester & $74.0(8.2)$ & $35.0(1.4)$ & 0 \\
indole-3-carboxylic acid & $93.1(0.9)$ & $41.5(0.2)$ & 0 \\
indole-3-carbinol & 0 & 0 & 0 \\
indole-3-acetic acid & $67.7(1.2)$ & $13.8(3.3)$ & $25.0(6.9)$ \\
indole-3-acetic acid ethyl ester & $40.8(3.6)$ & $25.0(1.3)$ & 0 \\
indole-3-glyoxylic acid & $89.4(3.5)$ & $8.0(1.1)$ & $92.3(0.8)$ \\
indole-3-acetamide & $100.0(0.1)$ & $95.8(0.6)$ & 0 \\
DL-indole-3-lactic acid & $82.7(9.1)$ & $12.3(2.9)$ & 0 \\
3- $\beta$-indoleacrylic acid & $17.5(0.3)$ & 0 & 0 \\
indole-3-propionic acid & $89.0(2.8)$ & $9.0(4.6)$ & 0 \\
indole-3-butyric acid & $98.7(1.55)$ & $2.0(1.9)$ & $95.0(0.1)$ \\
tryptamine & $98.7(0.7)$ & $96.7(0.1)$ & $97.3(0.8)$ \\
tryptophol & $98.3(0.2)$ & $97.2(0.9)$ & $95.0(2.1)$ \\
tryptophan & $98.3(1.1)$ & $95.0(3.2)$ & \\
\hline
\end{tabular}

a) Inner epidermis of coleoptile was floated onto a $0.5 \%$ methanol solution containing test compounds for $48 \mathrm{hr}$ and cytoplasmic streaming of epidermal cells was microscopically checked. The rates were expressed as percentage relative to the values of coleoptile tissues floated onto a methanol solution (control). The survival rates of the epidermis floated onto water and a methanol solution were $96.9 \pm 0.4$ and $92.3 \pm 0.8$, respectively. The data were given as average of four separate replications.

b) Test compounds were purchased from Sigma, St. Louis, MO., USA.

c) Concentrations $(\mu \mathrm{g} / \mathrm{ml})$.

d) Standard error.

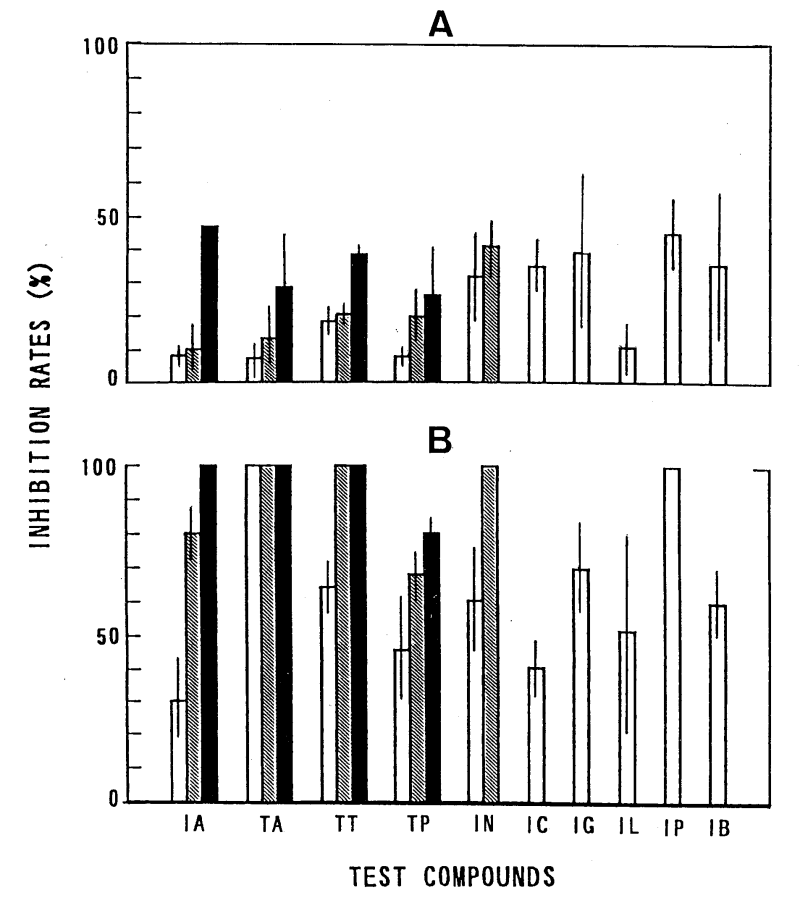

the inhibitory effect of these compounds against the development of the powdery mildew fungi inoculated onto coleoptile epidermis. The formation of appressoria was inhibited by all of the compounds treated, but their inhibition rates were not so conspicuous (less than $50 \%$ ). However, the haustorial formation was completely inhibited by the treatments with indole-3-acetamide,
Fig. 1. Inhibition of appressorial (A) and haustorial formation (B) of E. graminis f. sp. hordei, race I, by the treatment of indole derivatives. Inner epidermis of barley coleoptile was inoculated with race I and floated onto a solution containing

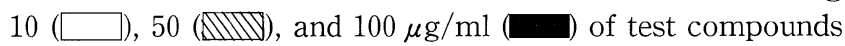
for $48 \mathrm{hr}$, and the fungal development was microscopically observed after checking cytoplasmic streaming in epidermal cells infected by the pathogen (infection sites). Three epidermal tissues were used in each experiment and approximately 100 infection sites per tissue were selected at random. The inhibition rates were calculated from the difference between the rates of appressorial or haustorial formation of the pathogen inoculated onto coleoptile epidermis floated onto a methanol (control) and test solution. The data were given as average of four separate experiments. Abbreviation: IA, indole-3-acetamide ; TA, tryptamine ; TT, tryptophol ; TP, tryptophan; IN, indole; IC, indole-3-carboxylic acid; IG, indole-3-glyoxylic acid ; IL, indole-3-lactic acid ; IP, indole-3propionic acid ; IB, indole-3-butyric acid.

tryptamine, tryptophol, indole, and indole-3-propionic acid. Especially, in the coleoptile epidermis treated with tryptamine or indole-3-propionic acid, the haustorial formation was effectively inhibited even when tested at the lowest concentration $(10 \mu \mathrm{g} / \mathrm{ml})$. Although the mechanisms of inhibition by these compounds have not been elucidated in the present study, some workers have 
reported the production of fluorescent antifungal compounds in barley leaves inoculated with E. graminis $\mathrm{f}$. sp. hordei ${ }^{1)}$ and Miyagawa et al. ${ }^{7)}$ successfully identified one of these compounds as tryptamine. These results strongly suggest that the powdery mildew fungi transformed with a certain gene for detoxifying tryptamine or indole-3-propionic acid could be propagated on barley coleoptile epidermis floated onto the selective solution. Our preliminary investigation indicated that Pseudomonas solanacearum was resistant to tryptamine because it was capable of metabolizing the compound and that this resistance could be destroyed by the insertion of a transposon to chromosome of this bacterium (unpublished data). The cloning of the tryptamine detoxifying gene from $P$. solanacearum chromosomal DNA is underway.

\section{Literature cited}

1. Kita, N., Toyoda, H. and Shishiyama, J. (1981). Chronological analysis of cytological responses in powderymildewed barley leaves. Can. J. Bot. 59 : 1761-1768.

2. Koga, H., Toyoda, H., Mayama, S. and Shishiyama, J. (1979). A new bioassay for detection of the substances to inhibit infection establishment of powdery mildew of barley. Ann. Phytopathol. Soc. Jpn. 45 : 258-260.

3. Matsuda, K., Toyoda, H., Yokoyama, K., Wakita, K., Nishio, H., Nishida, T., Dogo, M., Kakutani, K., Hamada, M. and Ouchi, S. (1993). Growth inhibition of Pseudomonas solanacearum by substituted 3 -indolepropionic acids and related compounds. Biosci. Biotech. Biochem. 57 : 1766-1767.

4. Matsuda, Y., Toyoda, H. and Ouchi, S. (1989). Application of microinjection to appressoria and haustoria of Erysiphe graminis f. sp. hordei. Ann. Phytopathol. Soc. Jpn. $55: 67-68$.

5. Matsuda, Y., Toyoda, H., Ikeda, S., Morita, M., Tamai, T. and Ouchi, S. (1993). Expression of a foreign gene in the barley powder mildew fungus analyzed by microinjection technique. Ann. Phytopathol. Soc. Jpn. 59 : 428431.

6. Matsuda, Y., Toyoda, H., Morita, M., Ikeda, S., Tamai, T., Nishiguchi, T. and Ouchi, S. (1994). A novel method for in situ hybridization in fungal cells based on prick- ing microinjection of photobiotin labelled probe. J Phytopathol. 144 : 133-142.

7. Miyagawa, H., Toda, H., Tsurushima, T., Ueno, T. and Shishiyama, J. (1994). Accumulation of tryptamine in barley leaves irradiated with UV light. Biosci. Biotech. Biochem. 58 : 1723-1724.

8. Tanpo, H., Toyoda, H., Nonomura, T. and Ouchi, S. (1994). Utilization of marker gene-integrated Fusarium oxysporum f. sp. fragariae for monitoring in planta. Ann. Phytopathol. Soc. Jpn. 60 : 225-227.

9. Toyoda, H., Matsuda, Y., Shoji, R. and Ouchi, S. (1987). A microinjection technique for conidia of Erysiphe graminis f. sp. hordei. Phytopathology 77 : 815-818.

10. Toyoda, H., Matsuda, K., Dogo, M., Kakutani, K., Akaza, K., Yamashita, S., Imanishi, Y., Matsuda, Y., Hamada, M. and Ouchi, S. (1991). Antibacterial activities of indole against Pseudomonas solanacearum (II). Inhibitory effect of indole derivatives on bacterial growth. Ann. Phytopathol. Soc. Jpn. 57 : 716-719.

11. Toyoda, H., Nishiguchi, T., Matsuda, Y., Nonomura, T. and Ouchi, S. (1992). In situ hybridization detection of mRNA in a filamentous phytopathogenic fungus, Fusarium oxysporum f. sp. lycopersici, by pricking microinjection of phtobiotin-labeled antisense RNA probe. Biosci. Biotech. Biochem. 56 : 1306-1307.

\section{和 文 摘 要}

道後充恵・豊田秀吉・松田克礼・松田一彦・国領ゆきえ・大内 成志：オオムギ子葉鞘接種うどんこ病菌の吸器形成を特異的に 抑制する化学物質の検索

宿主のオオムギ細胞を死滅させず，うどんこ病菌の吸器形成 のみを特異的に抑制する物質の検索を試みた。すなわち, 切離し たオオムギ子葉鞘内表皮にうどんこ病菌を接種し，種々の濃度 のインドール化合物の水溶液に浮遊させ, うどんこ病菌の吸器 形成に及ぼす影響を調べたところ，トリプタミンが顕著な選択 的効果を示した。すなわち, $100 \mu \mathrm{g} / \mathrm{ml}$ のトリプタミンを処理し た場合でも $95 \%$ 以上の宿主細胞が生存したのに対し，うどんこ 病菌の吸器形成は $10 \mu \mathrm{g} / \mathrm{ml}$ の処理で完全に阻害された。以上 の結果から，トリプタミン無毒化遺伝子のクローニングとこの 選抜化合物の併用によって，オオムギうどんこ病菌の形質転換 体選抜系が確立されるものと考えた。

(Received April 19, 1995 ; Accepted October 23, 1995) 